University of Nebraska - Lincoln

DigitalCommons@University of Nebraska - Lincoln

USDA National Wildlife Research Center - Staff

Publications

U.S. Department of Agriculture: Animal and Plant Health Inspection Service

2021

Factors Influencing Survival Rates of Pronghorn Fawns in Idaho

Brett R. Panting

Eric M. Gese

Mary M. Conner

Scott Bergen

Follow this and additional works at: https://digitalcommons.unl.edu/icwdm_usdanwrc

Part of the Natural Resources and Conservation Commons, Natural Resources Management and Policy Commons, Other Environmental Sciences Commons, Other Veterinary Medicine Commons, Population Biology Commons, Terrestrial and Aquatic Ecology Commons, Veterinary Infectious Diseases Commons, Veterinary Microbiology and Immunobiology Commons, Veterinary Preventive Medicine, Epidemiology, and Public Health Commons, and the Zoology Commons

This Article is brought to you for free and open access by the U.S. Department of Agriculture: Animal and Plant Health Inspection Service at DigitalCommons@University of Nebraska - Lincoln. It has been accepted for inclusion in USDA National Wildlife Research Center - Staff Publications by an authorized administrator of DigitalCommons@University of Nebraska - Lincoln. 


\title{
Factors Influencing Survival Rates of Pronghorn Fawns in Idaho
}

\author{
BRETT R. PANTING, Department of Wildland Resources, Utah State University, Logan, UT 84322-5230, USA \\ ERIC M. GESE, ${ }^{\mathbf{1}}$ United States Department of Agriculture, Wildlife Services, National Wildlife Research Center, Department of Wildland Resources, \\ Utah State University, Logan, UT 84322-5230, USA \\ MARY M. CONNER, Department of Wildland Resources, Utab State University, Logan, UT 84322-5230, USA \\ SCOTT BERGEN, Idaho Department of Fish and Game, Southeast Regional Office, Pocatello, ID 83204, USA
}

\begin{abstract}
Pronghorn (Antilocapra americana) occur throughout western North America. In Idaho, USA, following intensive hunting to reduce crop depredations in the late 1980s, pronghorn populations have not rebounded to desired levels. Because neonatal survival in ungulates is one factor limiting population growth, we evaluated cause-specific mortality and the influence of intrinsic and extrinsic factors on survival rates of 217 radio-collared pronghorn fawns across 3 study areas in Idaho during 2015-2016. For intrinsic variables, we determined the sex and body mass index (BMI) for each fawn. For extrinsic variables, we determined the abundance of predators and alternate prey, estimated the normalized difference vegetation index (NDVI) for 1 month pre- and post-parturition, and measured fecal nitrogen and diaminopimelic acid (DAPA). We considered NDVI as a measure of plant productivity, and fecal nitrogen and DAPA as possible proxies of diet quality. We predicted NDVI, fecal nitrogen, and DAPA would be positively related to the nutritional status of females and positively related to fawn survival. We used Program MARK with known fate models to estimate semi-monthly survival rates of pronghorn fawns for the first 4 months post-parturition. During both years, the leading cause of fawn mortality was coyote (Canis latrans) predation (58\%), followed by unknown causes of mortality (18\%), unknown predation (12\%), predation by bobcats (Lynx rufus; 6\%), predation by golden eagles (Aquila chrysaetos; 3\%), and other (3\%). Mean fawn survival for the 4 months post-parturition across years and study sites was $0.42 \pm 0.04$ $(\mathrm{SE}$; range $=28-62 \%)$. The top survival model included BMI, lagomorph abundance, and DAPA and had a model weight of $83.3 \%$. All 3 variables were positively related to pronghorn fawn survival. Because females with increased nutrition generally have heavier fawns, BMI was likely correlated to diet quality, which was supported by the positive relationship between DAPA and fawn survival. We hypothesize that high lagomorph abundance created an alternate prey base to buffer coyotes from preying on pronghorn neonates. We found no influence of measures of NDVI (pre- and post-parturition), fecal nitrogen, or predator abundance on fawn survival. Management actions providing high-quality forage for pronghorn are likely to contribute to production of heavier fawns having the highest chance of survival. (C) 2020 The Wildlife Society.
\end{abstract}

KEY WORDS Antilocapra americana, fawn, neonate, predation, pronghorn, survival.

Pronghorn (Antilocapra americana) were historically abundant throughout the central plains, western grasslands, and deserts of North America (Yoakum 2004a). Pronghorn are viewed by the public as an iconic symbol of the deserts and plains of the United States, and are a valued game animal for hunters in many states. In Idaho, USA, estimates of pronghorn numbers (Fig. 1) peaked in the late 1980s (Rachael et al. 2010). This increased abundance created increased crop depredation by pronghorn on local farms as pronghorn habitat was converted into irrigated agriculture in the Upper Snake River Plain. Pronghorn depredation on

Received: 3 April 2020; Accepted: 9 August 2020

${ }^{1}$ E-mail: eric.gese@usu.edu agricultural fields led to herds being heavily harvested to reduce numbers and mitigate conflicts with producers (Rachael et al. 2010). Since the reduction in pronghorn populations, Idaho has yet to see pronghorn numbers return to pre-control levels (Rachael et al. 2010). Because pronghorn are viewed as a valued big game animal, Idaho Department of Fish and Game (IDFG) has a mandate for sustaining pronghorn populations to provide hunting opportunities.

In general, ungulate populations have low fawn survival (Fowler 1987, Gaillard et al. 1998) and neonates are the most susceptible age class for morality (Caughley 1966, Fowler 1987, Linnell et al. 1995). Population dynamics of pronghorn populations are variable, but survival rates of pronghorn neonates are generally low (Gregg et al. 2001, 


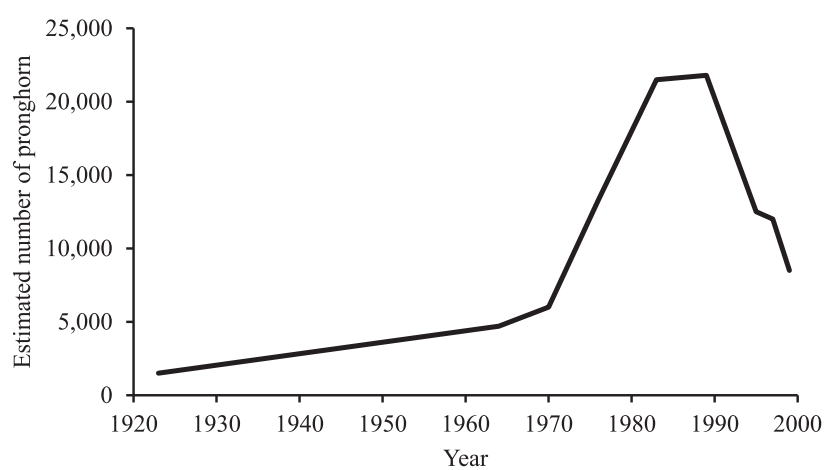

Figure 1. Estimated number of pronghorn in Idaho, USA, 1920-2000 (Yoakum 2004a).

Dunbar and Giordano 2003, Seidler et al. 2014). Survival of neonatal pronghorn are affected by a variety of factors including nutrition, predation, disease, and weather (Beale and Smith 1973, Byers 1997). Understanding the factors limiting neonatal survival could be important in sustaining or increasing pronghorn numbers to meet management objectives (i.e., increasing hunting opportunities). Adult survival in ungulate populations can remain stable but neonatal survival can be variable and play a large role in population dynamics (Gaillard et al. 1998).

The nutritional status of the female immediately before parturition can influence neonatal survival, and likely reflects the quality of forage available to the female during gestation (O'Gara 2004). Pronghorn diet quality can be indexed using fecal analysis (Yoakum 2004b) with 2 of the most common fecal measures being 2,6-diaminopimelic acid (DAPA) and fecal nitrogen (Leslie et al. 1989, Osborn and Ginnett 2001). Both have been studied in pronghorn in captivity (Robinson and Byers 2001) and free-ranging populations (Dennehy 2001, Hansen et al. 2001). In fecal samples, DAPA is an amino acid residue resulting from rumen bacteria fermentation with increasing levels of DAPA changing as diet quality increases (Dennehy 2001). Fecal nitrogen is the measure of nitrogen levels from undigested forage and is correlated to diet quality of ungulates (Wehausen 1995, Smyser et al. 2005). But Gálvez-Cerón et al. (2015) recommended fecal nitrogen is limited in its use as a proxy for diet quality because high levels of gastrointestinal nematodes influence fecal nitrogen in ruminants.

Predators can reduce ungulate neonate survival (Linnell et al. 1995). Coyotes (Canis latrans) account for upwards of $75 \%$ of predation-caused mortality on fawns (Berger and Conner 2008, White et al. 2009). Coyotes are generalist predators and consume a wide variety of prey species and neonates are vulnerable only within a short window following birth; therefore, predators are usually focused on alternate prey. Alternate prey affects neonatal survival in several ungulates including mule deer (Odocoileus hemionus; Hamlin et al. 1984), caribou calves (Rangifer tarandus; Bergerud 1983), and pronghorn (Beale 1986).

Pronghorn select forbs when they are available (Dirschl 1963, Beale and Smith 1970). Remote sensing has recently allowed for the incorporation of vegetation indices as indictors of plant productivity (Pettorelli 2014, Villamuelas et al. 2016) such as the normalized difference vegetation index (NDVI). The NDVI is the normalized reflectance difference between the visible red bands and the near infrared, and tracks chlorophyll quantity and plant production through the growing season (Pettorelli 2014, Jensen 2016, Villamuelas et al. 2016). Female pronghorn have a long gestation period (8.4 months) with half of a fawn's mass gained during the last month of pregnancy (O'Gara 2004). During this time, plant productivity (as measured by NDVI) could have a major influence on a fawn's birth mass during the pre-parturition period, and thus affect fawn survival.

Our objective was to examine intrinsic and extrinsic factors that may influence pronghorn fawn survival. We conducted the study at 3 sites to evaluate how a gradient of landscape differences may affect neonate survival. For intrinsic variables, we hypothesized that the sex and body mass index (BMI) of each fawn would influence fawn survival and predicted that larger fawns (i.e., males, fawns with higher BMI) would be related to increased fawn survival. For extrinsic variables, we hypothesized that the abundance of predators and alternative prey, estimated NDVI for 1 month pre- and post-parturition, and fecal nitrogen and DAPA would influence fawn survival. We predicted that greater NDVI (as a measure of plant productivity) and greater fecal nitrogen and DAPA (both surrogates of diet quality) would be related to increased fawn survival. We also predicted that a greater abundance of alternate prey and fewer predators would be related to increased fawn survival.

\section{STUDY AREA}

We conducted this study in 3 sites across Idaho (Fig. 2) during the summer (mid-May to mid-Sep) of 2015 and 2016. The 3,232- $\mathrm{km}^{2}$ Big Desert site consisted of variable topography with rolling lava ridges, grassy valleys, and sagebrush (Artemisia spp.) draws; elevation ranged from $1,395 \mathrm{~m}$ to $1,778 \mathrm{~m}$. Sagebrush and grasslands contained native (Indian ricegrass [Achnatherum hymenoides], needle-and-thread grass [Hesperostipa comate]), and invasive grasses (cheatgrass [Bromus tectorum]). There was a high portion of exotic invasive grasses in the area. At the eastern edge of the area, agricultural fields were present. Major fauna included pronghorn, elk (Cervus canadensis), coyotes, bobcats (Lynx rufus), and jackrabbits (Lepus spp.). Average annual rainfall was $23.31 \mathrm{~cm}$ and annual snowfall was $63.5 \mathrm{~cm}$ (www.usclimatedata.com, accessed 9 May 2017). Land ownership was 73\% Bureau of Land Management (BLM) and 25\% private, and the remaining $2 \%$ was split between the National Park Service and state. The Big Desert herd had approximately 250 pronghorn and was declining. In fall (Sep-early Nov), some pronghorn shifted to the agricultural fields, whereas during winter (late Nov-Mar), pronghorn either moved to the northwest, or resided along the eastern edge of the area.

The $1,008-\mathrm{km}^{2}$ Camas Prairie site was mainly private property. The topography was flat and primarily agricultural fields with some riparian areas; elevation ranged from $1,525 \mathrm{~m}$ to $1,589 \mathrm{~m}$. The agricultural fields consisted of alfalfa, wheat, 

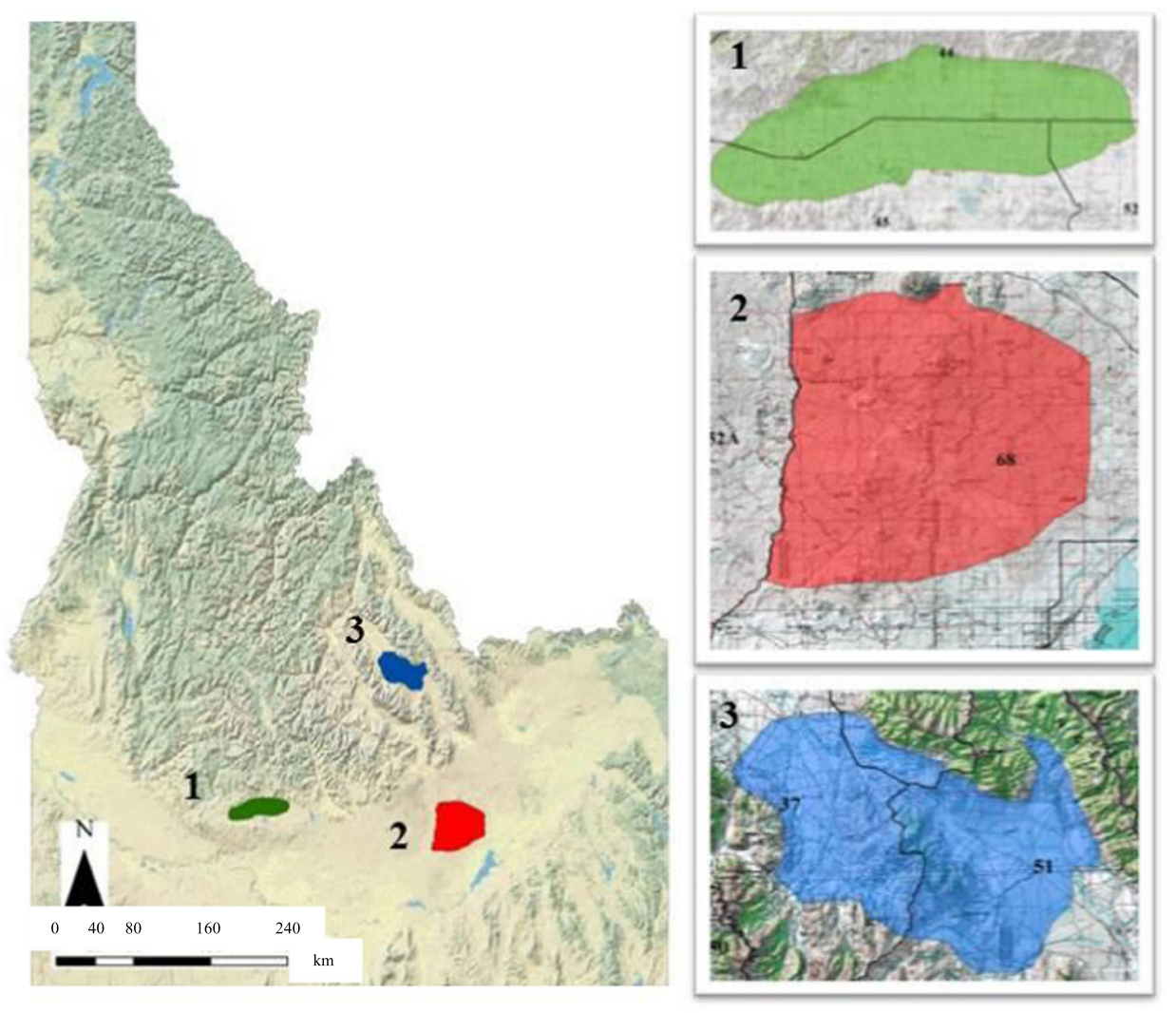

Figure 2. The 3 study areas for monitoring pronghorn fawn survival, southern Idaho, USA, 2015-2016. The Camas Prairie study area is denoted in green; Little Lost-Pahsimeroi study area is denoted in blue; Big Desert study area is denoted in red.

and grass. Major fauna included pronghorn, coyotes, jackrabbits, and ground squirrels (Urocitellus spp.). Annual rainfall averaged $33.8 \mathrm{~cm}$ and annual snowfall averaged $104.4 \mathrm{~cm}$. Land ownership was $97 \%$ private with the remaining split between state, United States Forest Service (USFS), and BLM. The Camas Prairie herd numbered approximately 800 animals and was slightly increasing. During the spring, summer, and fall, pronghorn lived almost exclusively in agriculture fields and surrounding riparian areas. During winter, all the pronghorn migrated to the south and southwest.

The $1,442-\mathrm{km}^{2}$ Little Lost-Pahsimeroi (LLPH) study site had variable topography with mountain peaks, creek bottoms, and sagebrush and grassy valleys; elevation ranged from $1,891 \mathrm{~m}$ to $2,992 \mathrm{~m}$. The site consisted of sagebrush flats and hills accompanied with creeks. Major fauna included pronghorn, elk, mule deer, coyotes, black bear (Ursus americanus), ground squirrels, and jackrabbits. Annual rainfall averaged $21.9 \mathrm{~cm}$ and annual snowfall averaged $40.6 \mathrm{~cm}$. Ownership was $78 \%$ BLM and $22.5 \%$ USFS, and the remaining $0.5 \%$ was split between state and private. The LLPH herd was stationary and numbered approximately 400 pronghorn. Most pronghorn moved out of the study area during winter.

\section{METHODS}

\section{Capture, Handling, and Monitoring of Fawns}

We captured newborn pronghorn during the fawning season (mid-May to early Jun) of 2015 and 2016. We observed female pronghorn suspected to be nursing newborn fawns using spotting scopes and binoculars. Once we observed a fawn, we directed capture teams to a fawn's location. Capture teams used large fishing nets placed over neonates when $2-3 \mathrm{~m}$ from the fawn. We then blindfolded the fawn and placed it in a mesh bag for processing. During handling, we wore rubber gloves and long-sleeve shirts to prevent transferring human scent to the fawn. We sexed, weighed, and measured (chest girth, hind foot length, hoof hairline) fawns, and estimated age using hair, umbilicus, and hoof condition (Autenrieth and Fichter 1975). We fitted each fawn with a 92-g expandable very high frequency radio-collar (Advanced Telemetry Systems, Isanti, MN, USA) equipped with a 4-hour mortality switch. Capture and handling protocols were reviewed and approved by the Institutional Animal Care and Review Committees (IACUC) at the United States Department of Agriculture, National Wildlife Research Center (protocol QA-2460) and Utah State University (IACUC approval 2443).

We located radio-collared neonates daily for up to 4 months using a 3-element Yagi antenna or an Omni-mounted truck antenna attached to a portable receiver (Communications Specialists, Orange, CA, USA). We used aerial flights to locate missing fawns. If we detected a mortality signal, we located the fawn immediately and performed a necropsy in the field, unless we found a whole carcass. We collected and froze whole carcasses and sent them to a diagnostic lab for necropsy (Idaho Wildlife Health Lab, Eagle, ID, USA). 


\section{Predator and Alternate Prey Surveys}

We conducted surveys in all 3 study areas, including predator scent-station surveys (Linhart and Knowlton 1975), lagomorph spotlight surveys (Smith and Nydegger 1985, Caley and Morley 2002), and ground squirrel surveys. We conducted the surveys on $45-\mathrm{km}$ transects located along roads, which we randomly selected in each study area. We used the same $45-\mathrm{km}$ transects for all the surveys in each study site during both years of the study. For scent-station surveys, we placed scent stations every $0.5 \mathrm{~km}$ along the transects giving 11 stations on every transect. Every station had a 1-m circle of leveled, sifted dirt containing a scented predator disc (Pocatello Supply Depot, Pocatello, ID, USA) in the center. We examined scent stations daily for 3 consecutive days (weather permitting) for predator tracks. We estimated relative abundance of predators as the visitation rate along each transect.

We completed lagomorph spotlight surveys on 3 consecutive nights along each transect, and counted black-tailed jackrabbits (Lepus californicus), white-tailed jackrabbits (Lepus townsendii), mountain cottontails (Sylvilagus nuttallii), pygmy rabbits (Brachylagus idahoensis), and snowshoe hares (Lepus americanus). We initiated lagomorph surveys for 3 consecutive nights during the onset of a new moon coinciding with neonate capture in all study areas. We determined abundance as rabbits per transect.

We estimated relative ground squirrel abundance using visual ground counts over 3 consecutive days and counted Uinta ground squirrels (Urocitellus armatus), Piute ground squirrels (U. mollis), Wyoming ground squirrels (U. elegans), Columbian ground squirrels (U. columbianus), and yellowbellied marmots (Marmota flaviventris). We determined abundance as squirrels per transect. We used the results from these 3 surveys in the pronghorn survival model at the study site level, the closest transect level (assigned fawns to the closest transect based on their capture site), or at the transect level using a random value within the standard deviation of the estimate for that transect, thereby accounting for variance of the estimate.

\section{Diet Quality and Plant Productivity Covariates}

We collected fecal samples to assess diet quality and female nutritional status on the study sites. We examined levels of DAPA and fecal nitrogen (Leslie et al. 1989, Osborn and Ginnett 2001). We collected fecal samples only from adult females across each site during late July through early August. We observed female pronghorn using spotting scopes and binoculars, marked locations when females deposited feces, then collected samples when the female moved away from that location. We collected approximately 50 samples from each study area per year. We froze collected samples and sent them to Washington State University Wildlife Habitat and Nutrition Lab (Pullman, WA, USA) for analysis of fecal nitrogen and DAPA. We averaged values of fecal nitrogen and DAPA across each study site for each year.

We examined NDVI as a measure of plant productivity (Pettorelli 2014, Jensen 2016, Villamuelas et al. 2016) as another extrinsic variable possibly influencing survival of pronghorn fawns. We acquired NDVI values from the United States Geological Survey eMODIS program (version 5) on a 7-day interval (https://phenology.cr.usgs.gov/ index.php, accessed 8 Sep 2017). We then formatted and entered the NDVI data into a time series analysis for the purposes of cleaning the data of atmospheric anomalies (i.e., clouds and smoke, which decrease NDVI values measured from satellite imagery) using a double logistic fitting algorithm (Bischof et al. 2012, Aikens et al. 2017, Mysterud et al. 2017) using TimeSat 3.3 software (http://web.nateko. lu.se/timesat/timesat.asp, accessed 11 May 2017). We then entered the appropriate weekly NDVI images into a geographic information system.

We collected NDVI values during 2 different phases: preparturition and post-parturition using capture date and location to determine the location and timing of the NDVI data. We examined NDVI measures during 4 weeks preparturition to represent maternal nutrition during the last month of pregnancy, which could affect fitness of the fawn. We also examined NDVI measures during 4 weeks postparturition to determine if there was a vegetative concealment component or increased milk production (i.e., during lactation) associated with fawn survival. We calculated the parturition date for each capture site. We used this date to determine which 4 weeks of NDVI data to use for the preand post-parturition NDVI values for each fawn and created a 1-km buffer around each fawn's capture location. We then used weekly averaged and accumulated sums of the NDVI values within the capture location buffer to estimate average and total productivity for each fawn during the pre- and post-parturition periods. Pre-parturition locations were unknown prior to birth of the fawn (i.e., the female was not radio-collared). Post-parturition locations (first 4 weeks after capture) of the radio-collared fawns were within the $1-\mathrm{km}$ buffer of the capture site.

\section{Data Analysis}

We used the known fate model in Program MARK (White and Burnham 1999) to estimate survival rates of the radiocollared pronghorn fawns. The model is an extension of the Kaplan-Meier model (Kaplan and Meier 1958) and allows staggered entry and exit of fawns (Pollock et al. 1989). We estimated fawn survival in 8 bi-weekly intervals, which occurred late May (following parturition) through midSeptember. We assigned fawns an alive or dead status for each survival period and censored fawns not located during the period.

We constructed models to assess patterns in neonatal pronghorn survival across a range of environmental conditions. To avoid developing a large number of a priori models, we used a sequential process (Nichols et al. 1997, Franklin et al. 2004, Blakesley et al. 2010). In the first phase, we constructed models with sex, temporal (within and between yr), and study site effects. We used the structure from the top models (top model and models $\leq 2 \Delta \mathrm{AIC}_{c}$ units of top model) in the first phase and then included individual covariates and site variables. We included each 
covariate in the base model separately, as an additive effect. Individual covariates included fawn DAPA (average DAPA from the 3 closest fecal samples to the fawn capture site), mean predator abundance for each fawn (estimated predator abundance from the transect closest to fawn capture site), and random predator abundance for each fawn (a randomly generated number within the standard deviation for the transect closest to the fawn capture site). In addition, to control for age and size differences, we included hind foot length and BMI as individual covariates (BMI calculated for each fawn using a fawn's mass divided by chest girth). During this phase, we also evaluated site covariates of preparturition NDVI for each capture location, postparturition NDVI for each capture location, mean fecal nitrogen value for each study site, mean fecal DAPA for each study site, mean predator abundance for each study site, mean lagomorph abundance for the study site, lagomorph transect average, lagomorph transect random, squirrel site-wide average, squirrel transect average, and squirrel transect random (Table 1). For the variables of predator, lagomorph, and squirrel abundance, there were 3 indices of abundance (i.e., mean for the study site, transect average, and transect random), but we included only 1 of these indices in any model.

After analyzing the second phase of models, we expected to construct our final set of models using combinations of variables contained in the top models (top model and models $\leq 2 \Delta \mathrm{AIC}_{c}$ units of top model); however, $\mathrm{BMI}$ was the only competitive variable. The model with $\mathrm{BMI}$ was $7.54 \mathrm{AIC}_{c}$ units lower than the next best model with any of the predictor variables. Therefore, for the third and final set of models, we combined every variable for which the AIC $c$ was lower than the base model with BMI. Although DAPA, pre-parturition NDVI and post-parturition NDVI

Table 1. Intrinsic and extrinsic predictor variables hypothesized to influence survival of neonatal pronghorn, southern Idaho, USA, 2015-2016.

\begin{tabular}{lll}
\hline $\begin{array}{l}\text { Predictor } \\
\text { category }\end{array}$ & \multicolumn{1}{c}{ Variable $^{\text {a }}$} & $\begin{array}{c}\text { Type of } \\
\text { variable }\end{array}$ \\
\hline Fawn & Body mass index & Individual \\
Fawn & Hind foot length & Individual \\
Fawn & Sex & Individual \\
Temporal & Year & Temporal \\
Temporal & 2-week period & Temporal \\
Site & Site difference (beyond habitat variables) & Site \\
Habitat & Fecal nitrogen site-wide & Site \\
Habitat & DAPA site-wide & Site \\
Habitat & Fawn DAPA (3 closest samples) & Individual \\
Habitat & Pre-parturition NDVI & Individual \\
Habitat & Post-parturition NDVI & Individual \\
Environmental & Predator site-wide & Site \\
Environmental & Predator transect & Individual \\
Environmental & Predator transect random & Individual \\
Environmental & Lagomorph site-wide & Site \\
Environmental & Lagomorph transect & Individual \\
Environmental & Lagomorph transect random & Individual \\
Environmental & Squirrel site-wide & Site \\
Environmental & Squirrel transect & Individual \\
Environmental & Squirrel transect random & Individual \\
\hline
\end{tabular}

${ }^{\text {a }} \mathrm{DAPA}=2$,6-diaminopimelic acid; NDVI = normalized difference vegetation index. did not meet these criteria, we also included these 3 variables in the final model set. We included these variables because a major impetus for this study was to determine whether DAPA or an NDVI metric could serve as a proxy for habitat quality for pronghorn fawning areas. We used Akaike's Information Criterion for small sample sizes $\left(\mathrm{AIC}_{c}\right)$ and normalized $\mathrm{AIC}_{c}$ weights to rank the models (Burnham and Anderson 2002). To account for model selection uncertainty, if applicable, we used model-averaged estimates of fawn survival.

Neonatal ungulates are often radio-collared as siblings (Hamlin et al. 1984, Whittaker and Lindzey 1999, Carstensen et al. 2003, Bishop et al. 2007) for those species that twin. We radio-collared each fawn we could locate, resulting in $48.3 \%$ of the radio-collared fawns being siblings. When sampling units include siblings, independence of sampling units can be violated (Bishop et al. 2008). We tested for lack of independence, via estimating an overdispersion parameter $(c)$, using our global model. We used the data bootstrap (commonly referred to as a non-parametric bootstrap in statistical literature) procedure in Program MARK (White and Burnham 1999, Bishop et al. 2008) to run 5,000 simulations. To estimate $c$, we divided the bootstrap variance by the estimated variance from the global model. We estimated $c$ separately for each study site.

\section{RESULTS}

We captured, radio-collared, and monitored 217 (110 female, 107 male) fawns during 2015 and 2016. In 2015, we radiocollared 101 (51 female, 50 male) fawns over 19 days. In 2016, we radio-collared 116 (59 female, 57 male) fawns over 21 days. The number for each site and year varied (Table 2), but we approached our target of 30 fawns/site/year. Mean fawn capture date was similar among years and study sites (Table 2); we censored the 1 mortality classed as capturerelated from analysis. The mean body mass of fawns at capture during the entire study was $3.99 \mathrm{~kg}$ and mean chest girth was $36.95 \mathrm{~cm}$. In 2015 , mean body mass across the study areas was $3.87 \mathrm{~kg}$ with a mean chest girth of $36.81 \mathrm{~cm}$. In 2016, the mean body mass was $4.09 \mathrm{~kg}$ and mean chest girth was $36.95 \mathrm{~cm}$. Body measurements of fawns varied among study sites and years (Table 2). The mean BMI of all fawns at capture was 0.108 across all years and study sites. In 2015 and 2016, the mean BMI was 0.105 and 0.110, respectively.

The percent fawns surviving and causes of death varied among years and sites (Table 3). In 2015, across all sites, coyote predation was responsible for $61 \%$ of mortalities, followed by unknown mortality (19\%), unknown predation (9\%), bobcats (5\%), golden eagles (Aquila chrysaetos; 4\%), and black bears (2\%). In 2016, across all sites, coyote predation was again the leading cause of mortality (56\%), followed by unknown causes (16\%), unknown predation $(15 \%)$, bobcats $(7 \%)$, golden eagles $(3 \%)$, pneumonia $(2 \%)$, and capture (1\%).

\section{Predator and Alternate Prey Surveys}

We used 264 scent stations over 18 survey nights to estimate predator abundance (Table 4). The Big Desert study site 
Table 2. Number of fawns captured and radio-collared, sex ratio, mean capture date, body mass, chest girth, and body mass index of neonatal pronghorn across the 3 study areas, southern Idaho, USA, 2015-2016.

\begin{tabular}{|c|c|c|c|c|c|c|}
\hline & \multicolumn{2}{|c|}{ Big Desert } & \multicolumn{2}{|c|}{ Camas Prairie } & \multicolumn{2}{|c|}{ Little Lost-Pahsimeroi } \\
\hline & 2015 & 2016 & 2015 & 2016 & 2015 & 2016 \\
\hline Number captured & 32 & 40 & 33 & 37 & 36 & 39 \\
\hline Capture date $(\bar{x})$ & 26 May & 19 May & 27 May & 25 May & 25 May & 23 May \\
\hline \multicolumn{7}{|l|}{ Fawn mass $(\mathrm{kg})$} \\
\hline $\bar{x}$ & 4.2 & 4.1 & 3.7 & 3.8 & 3.7 & 4.4 \\
\hline SD & 0.8 & 0.8 & 0.5 & 0.8 & 0.7 & 0.5 \\
\hline \multicolumn{7}{|l|}{ Chest girth $(\mathrm{cm})$} \\
\hline $\bar{x}$ & 38.1 & 37.5 & 36.2 & 37.3 & 36.2 & 36.5 \\
\hline SD & 3.2 & 2.7 & 2.4 & 5.1 & 2.7 & 1.9 \\
\hline Min. & 32.0 & 31.0 & 30.7 & 27.0 & 30.5 & 32.0 \\
\hline Max. & 46.0 & 45.0 & 41.0 & 49.0 & 43.5 & 40.0 \\
\hline \multicolumn{7}{|l|}{ Body mass index } \\
\hline
\end{tabular}

had the highest estimates of relative predator abundance during both years. Coyotes were the leading predator found in all of the surveys. In 2015 and 2016, the Big Desert study site had the highest number of coyote visits per transect, followed by the LLPH site, then the Camas Prairie site. We found sign of bobcats only in the Big Desert study site in 2015 and abundance estimates averaged $1.0 \pm 1.47$ (SD) bobcat visits/transect. In 2016, the Big Desert site recorded an average of $0.08 \pm 0.28$ bobcat visits/transect and the Camas Prairie site averaged $0.33 \pm 0.49$ bobcat visits/ transect. The LLPH study site did not have bobcats visit any scent station in 2015 or 2016.

We completed 72 nights of spotlight surveys to estimate relative lagomorph abundance and counted 626 lagomorphs (Table 4). We counted 309 lagomorphs in 2015 and 317 in 2016. Black-tailed jackrabbits were the most abundant lagomorph (81.5\%) with 510 rabbits counted across both years. White-tailed jackrabbits were the second most abundant $(n=60)$, followed by cottontail rabbits $(n=34)$,

Table 3. Percent fawns surviving the first 4 months post-birth and percent cause-specific mortality of neonatal pronghorn across the 3 study areas, southern Idaho, USA, 2015-2016.

\begin{tabular}{|c|c|c|c|c|c|c|}
\hline & \multicolumn{2}{|c|}{ Big Desert } & \multicolumn{2}{|c|}{ Camas Prairie } & \multicolumn{2}{|c|}{$\begin{array}{l}\text { Little Lost- } \\
\text { Pahsimeroi }\end{array}$} \\
\hline & 2015 & 2016 & 2015 & 2016 & 2015 & 2016 \\
\hline \multicolumn{7}{|l|}{ Fawns surviving } \\
\hline$\%$ surviving & 51 & 35 & 50 & 62 & 28 & 28 \\
\hline \multicolumn{7}{|l|}{ Cause $(\%)$} \\
\hline Coyote predation & 34 & 54 & 81 & 43 & 65 & 64 \\
\hline Unknown causes & 13 & 15 & 19 & 21 & 23 & 14 \\
\hline Bobcat predation & 20 & 19 & & & & \\
\hline Unknown predation & 33 & 12 & & 29 & & 11 \\
\hline Eagle predation & & & & & 8 & 7 \\
\hline Bear predation & & & & & 4 & \\
\hline Pneumonia & & & & 7 & & \\
\hline Capture & & & & & & 4 \\
\hline
\end{tabular}

and pygmy rabbits $(n=7)$. The Big Desert site had the highest lagomorph abundance during both years. In 2015 and 2016, the Big Desert site had the highest number of lagomorphs per transect, followed by the LLPH site, then the Camas Prairie site.

We surveyed ground squirrels on 72 days during the study and counted 235 ground squirrels in 2015, and 144 in 2016 (Table 4). The Camas Prairie site had the highest ground squirrel abundance for both years. In 2015 and 2016, the Camas Prairie site had the highest number of squirrels per transect, followed by the LLPH site, then the Big Desert site.

\section{Fecal Nitrogen and DAPA}

In 2015, we collected 134 fecal samples (Big Desert: $n=50$, Camas Prairie: $n=44$, LLPH: $n=40$ ). The Camas Prairie site had the highest values of fecal nitrogen and DAPA, followed by the Big Desert site, and then the LLPH site (Fig. 3). In 2016, we collected 150 (50 at each site) fecal

Table 4. Relative abundance of ground squirrels, lagomorphs, and predators across the 3 study areas, southern Idaho, USA, 2015-2016.

\begin{tabular}{|c|c|c|c|c|c|c|}
\hline & \multicolumn{2}{|c|}{ Big Desert } & \multicolumn{2}{|c|}{ Camas Prairie } & \multicolumn{2}{|c|}{ Little Lost-Pahsimero } \\
\hline & 2015 & 2016 & 2015 & 2016 & 2015 & 2016 \\
\hline \multicolumn{7}{|c|}{ Ground squirrel abundance (squirrels/transect) } \\
\hline $\bar{x}$ & 0.0 & 0.3 & 13.8 & 6.1 & 5.8 & 5.6 \\
\hline SD & 0.0 & 0.7 & 20.9 & 11.6 & 4.0 & 4.4 \\
\hline Range & 0.0 & $0-2$ & $0-54$ & $0-32$ & $0-12$ & $1-15$ \\
\hline \multicolumn{7}{|c|}{ Lagomorph abundance (rabbits/transect) } \\
\hline $\bar{x}$ & 21.0 & 21.2 & 1.5 & 2.0 & 3.3 & 3.2 \\
\hline SD & 15.4 & 13.7 & 1.8 & 1.8 & 3.6 & 4.3 \\
\hline Range & $1-48$ & $3-45$ & $0-6$ & $0-5$ & $0-10$ & $0-15$ \\
\hline \multicolumn{7}{|c|}{ Predator abundance (predator visits/transect) } \\
\hline $\bar{x}$ & 2.3 & 2.4 & 0.2 & 0.8 & 0.5 & 1.3 \\
\hline SD & 1.9 & 1.3 & 0.4 & 1.1 & 0.8 & 0.9 \\
\hline Range & $0-6$ & $0-5$ & $0-1$ & $0-3$ & $0-2$ & $0-3$ \\
\hline
\end{tabular}




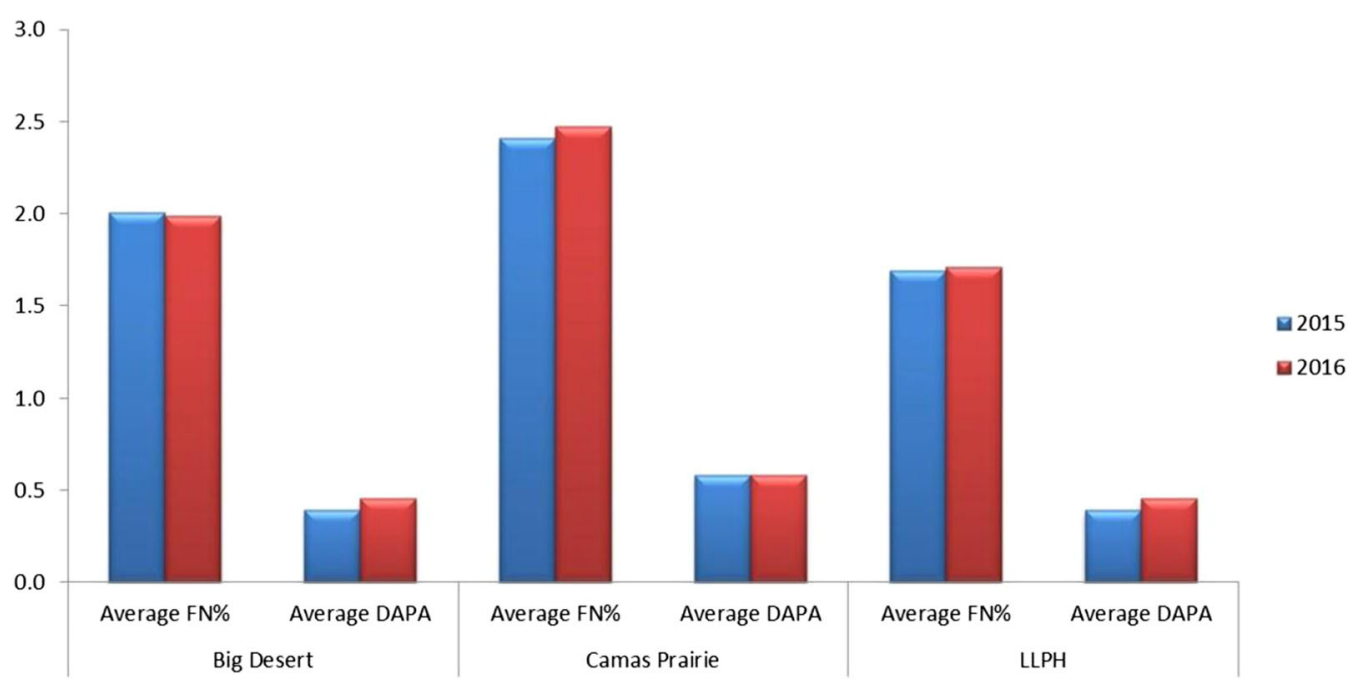

Figure 3. Mean values of 2,6-diaminopimelic acid (DAPA; $\mathrm{mg} / \mathrm{g}$ ) and percent fecal nitrogen (FN\%) determined from fecal samples collected from adult females across the 3 study sites, southern Idaho, USA, 2015-2016. LLPH = Little Lost-Pahsimeroi.

samples across the study sites. The Camas Prairie site again had the highest values for fecal nitrogen and DAPA, followed by the Big Desert site, and the LLPH again had the lowest fecal nitrogen and DAPA values. The DAPA and fecal nitrogen values were correlated in space and time with both parameters being high during the same years and same sites.

\section{Survival Analysis}

Estimates of $c$ for each study site (group) were $\leq 1$ indicating no issues of overdispersion or dependence in the dataset. The top model for the first phase of model selection included site and time modeled as categorical variables (Table 5). Categorical time indicates survival was different for each semi-monthly period, both within and between years, but with no trend. For the second phase of modeling, BMI was the highest-ranked single covariate or variable (Table 5). The next closest covariate to BMI was relative abundance of lagomorphs at the transect level $\left(\Delta \mathrm{AIC}_{c}=7.5\right)$. The best model from the first and second phase of modeling indicated no strong increasing or decreasing temporal trends in survival, and no influence of sex on survival rates.

We omitted the variable random lagomorphs per transect from the third data set because its $\mathrm{AIC}_{c}$ was larger than the closely related lagomorphs per transect and its parameter (slope) estimate was not significant (at $\alpha=0.05$ ), whereas the parameter for lagomorphs per transect was significant. When we combined BMI with final variables from the second phase of modeling, abundance of lagomorphs per transect and DAPA at the study site level were in the top models (Table 5). Because we hypothesized lagomorph abundance was what explained the site differences, we ran a final model wherein we removed site and ran a model with BMI, lagomorphs per transect, and DAPA. This was the top model and had $83.3 \%$ of the model weight (Table 5). The second-best model contained the same covariates as the previous model but had an additive group (study site) effect; this model had $11.2 \%$ of model weight. These 2 top models explained $94.5 \%$ of the model weight. In both top models, survival rates of pronghorn fawns increased with increasing individual BMI (Fig. 4A), increasing lagomorph abundance (Fig. 4B) and increasing DAPA values for adult female pronghorn at the study site level (Fig. 4C). Overall survival of pronghorn fawns for the 4-month study period during 2015 and 2016 was $0.42 \pm 0.04$ (SE) and $0.41 \pm 0.04$, respectively.

\section{DISCUSSION}

Our results supported the hypothesis that BMI of neonates, lagomorph abundance, and levels of DAPA among the females were related to fawn survival. The BMI of the neonates and the DAPA values among the adult females are often linked to diet quality (Robinson and Byers 2001, Miller and Drake 2003, Smyser 2008). Because pronghorn fawns gain half of their body mass during the last month of gestation (O'Gara 2004), female pronghorn need highly nutritious plant species, mostly forbs, during late gestation and lactation (Yoakum 2006). Lactation is very energetically expensive to the female and having a high nutritional status entering lactation would be equally advantageous. Thus, a high-quality diet for the female during pregnancy and into lactation plays a role in fawn survival. The Camas Prairie study site had the highest survival during both years, which we predicted based upon the high occurrence and use of alfalfa fields by the local pronghorn population. These alfalfa fields are providing adult females with highly nutritious forage as reflected in the high DAPA values at this site (Fig. 3). Therefore, diet quality during gestation and subsequent lactation may be the major factors influencing pronghorn fawn survival in Idaho. We did not estimate diet or forage quality as part of our study, which requires additional investigation to understand their quantitative contributions to pronghorn fawn survival.

The relationship between increasing BMI and increasing neonatal survival is consistent with other studies of ungulates. Pronghorn fawns with higher body mass generally have higher chances of survival, as similarly found in mule 
Table 5. Models for known-fate survival (S) analysis of neonatal pronghorn for 4 months post-birth in southern Idaho, USA, 2015-2016. We present Akaike's Information Criterion corrected for small sample sizes $\left(\mathrm{AIC}_{c}\right)$, difference in $\mathrm{AIC}_{c}\left(\Delta \mathrm{AIC}_{c}\right)$, model weight $\left(w_{i}\right)$, model likelihood, number of parameters $(K)$, deviance, and model phase. Model phase indicates which model set each model was in.

\begin{tabular}{|c|c|c|c|c|c|c|c|}
\hline Model $^{\mathrm{a}}$ & $\mathrm{AIC}_{c}$ & $\Delta \mathrm{AIC}_{c}$ & $w_{i}$ & Model likelihood & $K$ & Deviance & Model phase \\
\hline $\mathrm{S}(\mathrm{t})+\mathrm{BMI}+$ lagotran + DAPAsite & 644.426 & 0.000 & 0.833 & 1.000 & 11 & 622.160 & 3 \\
\hline $\mathrm{S}(\mathrm{g}+\mathrm{t})+\mathrm{BMI}+$ lagotran + DAPAsite & 648.435 & 4.009 & 0.112 & 0.135 & 13 & 622.067 & 3 \\
\hline $\mathrm{S}(\mathrm{g}+\mathrm{t})+\mathrm{BMI}+$ DAPAsite & 651.732 & 7.306 & 0.022 & 0.026 & 12 & 627.417 & 3 \\
\hline $\mathrm{S}(\mathrm{g}+\mathrm{t})+\mathrm{BMI}+$ lagotran + DAPAfawn & 653.502 & 9.076 & 0.009 & 0.011 & 13 & 627.134 & 3 \\
\hline $\mathrm{S}(\mathrm{g}+\mathrm{t})+\mathrm{BMI}^{\mathrm{b}}$ & 656.350 & 11.924 & 0.002 & 0.003 & 11 & 634.083 & 2 \\
\hline $\mathrm{S}(\mathrm{g}+\mathrm{t})+\mathrm{BMI}+\mathrm{DAPAfawn}$ & 656.734 & 12.308 & 0.002 & 0.002 & 12 & 632.419 & 3 \\
\hline $\mathrm{S}(\mathrm{t})+\mathrm{BMI}$ + lagotran + DAPAfawn & 657.478 & 13.052 & 0.001 & 0.002 & 11 & 635.212 & 3 \\
\hline $\mathrm{S}(\mathrm{g}+\mathrm{t})+\mathrm{BMI}+$ preNDVI & 658.029 & 13.603 & 0.001 & 0.001 & 12 & 633.714 & 3 \\
\hline $\mathrm{S}(\mathrm{g}+\mathrm{t})+\mathrm{BMI}+$ postNDVI & 658.358 & 13.932 & 0.001 & 0.001 & 12 & 634.043 & 3 \\
\hline$S(g+t)+$ lagotran & 663.804 & 19.378 & 0.000 & 0.000 & 11 & 641.537 & 2 \\
\hline $\mathrm{S}(\mathrm{g}+\mathrm{t})+$ lagorand & 666.540 & 22.114 & 0.000 & 0.000 & 11 & 644.274 & 2 \\
\hline $\mathrm{S}(\mathrm{g}+\mathrm{t})+$ FNsite & 666.836 & 22.410 & 0.000 & 0.000 & 11 & 644.570 & 2 \\
\hline$S(g+t)+$ hindfoot & 667.734 & 23.308 & 0.000 & 0.000 & 11 & 645.467 & 2 \\
\hline $\mathrm{S}(\mathrm{g} \times \mathrm{t})$ & 668.108 & 13.228 & 0.001 & 0.001 & 24 & 618.881 & 1 \\
\hline$S(g+t)+$ sqlrand & 668.727 & 24.300 & 0.000 & 0.000 & 11 & 646.460 & 2 \\
\hline$S(g+t)+$ year & 669.026 & 24.599 & 0.000 & 0.000 & 11 & 646.759 & 2 \\
\hline $\mathrm{S}(\mathrm{g}+\mathrm{t})+$ predtran & 669.068 & 24.642 & 0.000 & 0.000 & 11 & 646.802 & 2 \\
\hline$S(g+t)+$ sqlrand & 669.102 & 24.677 & 0.000 & 0.000 & 11 & 646.836 & 2 \\
\hline $\mathrm{S}(\mathrm{g}+\mathrm{t})+$ predsite & 669.116 & 24.690 & 0.000 & 0.000 & 11 & 646.849 & 2 \\
\hline $\mathrm{S}(\mathrm{g}+\mathrm{t})+$ lagosite & 669.185 & 24.759 & 0.000 & 0.000 & 11 & 646.918 & 2 \\
\hline $\mathrm{S}(\mathrm{g}+\mathrm{t})+$ postNDVI & 669.199 & 24.773 & 0.000 & 0.000 & 11 & 646.933 & 2 \\
\hline $\mathrm{S}(\mathrm{g}+\mathrm{t})+$ preNDVI & 669.260 & 24.834 & 0.000 & 0.000 & 11 & 646.994 & 2 \\
\hline$S(g+t)+\operatorname{sex}$ & 669.263 & 24.837 & 0.000 & 0.000 & 11 & 646.996 & 2 \\
\hline $\mathrm{S}(\mathrm{t})$ & 682.401 & 37.975 & 0.000 & 0.000 & 8 & 666.257 & 1 \\
\hline $\mathrm{S}(\mathrm{g})$ & 723.593 & 79.166 & 0.000 & 0.000 & 3 & 717.569 & 1 \\
\hline
\end{tabular}

${ }^{a}$ Covariates include body mass index (BMI), hind foot length (hindfoot), sex (sex), year (year), 2-week period (t), site (g), fecal nitrogen site-wide (FNsite), 2,6-diaminopimelic acid site-wide (DAPAsite), fawn DAPA using 3 closest samples (DAPAfawn), pre-parturition normalized difference vegetation index (preNDVI), post-parturition NDVI (postNDVI), predator abundance site-wide (predsite), predator abundance per transect (predtran), predator abundance per transect random (predrand), lagomorph abundance site-wide (lagosite), lagomorph abundance per transect (lagotran), lagomorph abundance per transect random (lagorand), squirrel abundance site-wide (sqlsite), squirrel abundance per transect (sqltran), and squirrel abundance per transect random (sqlrand).

b Top model for phase 2 of model construction.

c Top models for phase 1 of model construction.

deer (Bishop et al. 2009, Monteith et al. 2014), white-tailed deer (O. virginianus; Sams et al. 1996, Carstensen et al. 2009), and moose (Alces alces; Keech et al. 2000). Neonates with lower birth mass had lower survival in pronghorn in Colorado, USA (Fairbanks 1993). In our study, sites in which female pronghorn had higher DAPA values generally produced fawns with a higher BMI, which then subsequently had higher survival. Although coyote predation was the proximate cause of death in most cases, survival models indicated that nutritional status of the female and the BMI of her offspring ultimately determine the fate of that fawn. High DAPA values are linked to highquality forage (Miller and Drake 2003, Smyser 2008). Female pronghorn feeding on lower nutritional quality forage results in lower neonatal birth mass, which in turn directly influences neonate survival (Robbins 1983, Miller and Drake 2003). Nutritional differences in fecal samples reflect pronghorn fawn survival (Smyser 2008). With the relationship between fawn survival and DAPA, it may be possible to use DAPA as an indirect means to monitor pronghorn fawn survival. Future studies would benefit from collecting DAPA samples near radio-collared neonates, thereby providing inferences about DAPA values at the individual level. Inference at an individual level would provide strong evidence that DAPA could be used as a surrogate for female nutritional status. Collecting samples across seasons could also be used to monitor changes in female nutrition during other critical times (e.g., during gestation, or during winter). Capturing and marking individual females would also provide the added benefit of tracking individual nutritional status and subsequent fawn survival.

As predicted, we found a relationship between increasing lagomorph abundance and increasing fawn survival rates. 


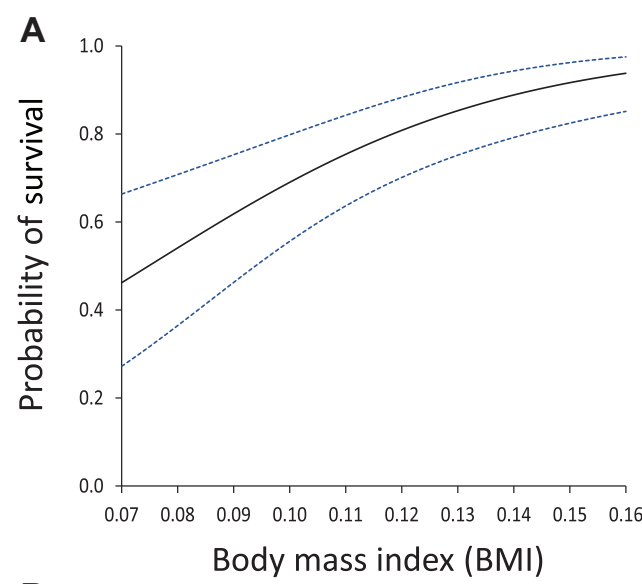

B
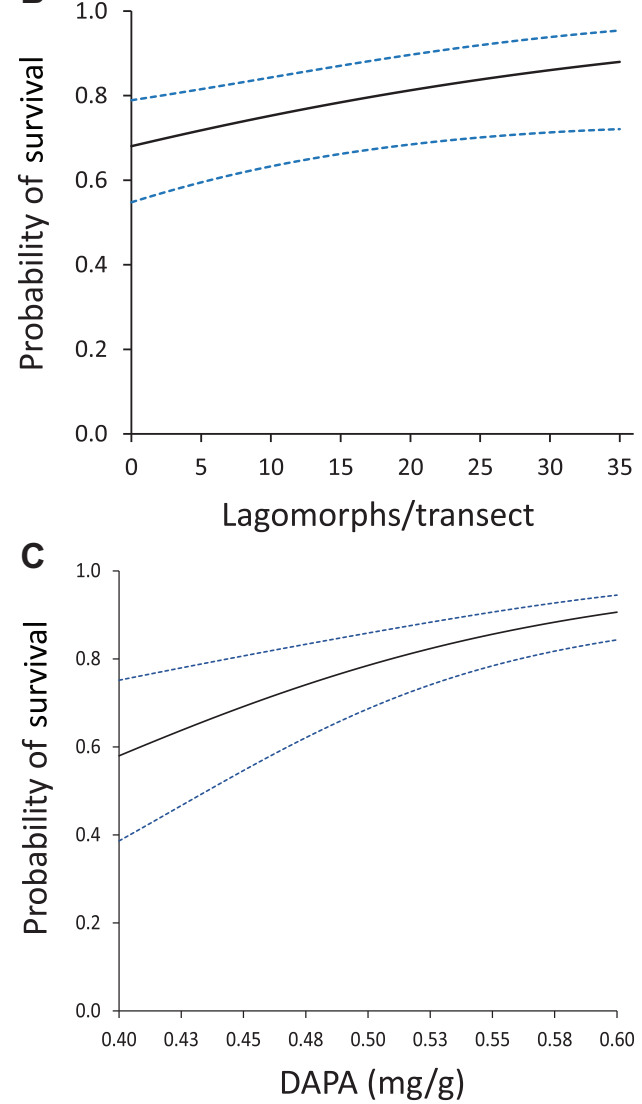

Figure 4. Model averaged estimates of semi-monthly post-birth survival probabilities of pronghorn fawns as related to A) body-mass index (BMI) of fawns, B) abundance of lagomorphs, and C) levels of 2,6diaminopimelic acid (DAPA; $\mathrm{mg} / \mathrm{g}$ ) in adult females, southern Idaho, USA, 2015-2016. All other model covariates are held at their average values to generate estimates; estimates are for site 1 and time-period 2 (slopes are the same for all sites and time periods). Dashed lines represent $95 \%$ confidence intervals.

Predators may be satiated with alternate prey during periods when prey are abundant, thereby buffering the need for coyotes to prey on fawns during a neonate's vulnerable time (Hamlin et al. 1984, Berger et al. 2008). Our study supported this premise, whereas a previous study found rabbit abundance did not influence fawn survival in southeastern Colorado (Seidler et al. 2014). Lagomorphs have population cycles throughout the Intermountain West (Clark 1972,
Wagner 1981, Stoddart et al. 2001) and how these cycles influence fawn survival is presently unknown. It may be that there is some threshold of density for alterative prey that facilitates prey switching, and during our study, rabbit density was above this threshold. Differences in the relationship between fawn survival and lagomorph abundance among the sites could be related to differences in lagomorph densities, and lagomorph densities could be influenced by differences in position on the lagomorph population cycle (Clark 1972, Wagner 1981, Knowlton and Stoddart 1992), or overall differences in habitat characteristics among sites. Although alternate prey appeared to be buffering pronghorn fawns from coyote predation during the 2 years of our study, there is a possible negative effect of alternate prey subsidizing (Rominger et al. 2004) and increasing predator populations (Knowlton and Stoddart 1992, Knowlton et al. 1999). Apparent competition (Holt 1977) can be deleterious to small ungulate populations where predator populations are sustained at high densities by the presence of alternate prey (Johnson et al. 2013).

Contrary to our hypothesis, we did not find pre- or postparturition values of NDVI influenced fawn survival. Pronghorn are very selective foragers (Yoakum 1990) and select for high-quality forage (Yoakum 1990, 2004b). It is likely they select for small forbs in a sea of sagebrush, which may render our NDVI an inaccurate measure of plant productivity for pronghorn. That is, our NDVI imagery was at a resolution of $250 \mathrm{~m}$, and that coarse resolution would not represent the fine-scale plant selection of pronghorn. Given this lack of spatial scale alignment, it is not surprising fawn survival was unrelated to NDVI metrics. Similarly, there was no relationship between NDVI and survival of adult Sierra Nevada bighorn sheep (Ovis canadensis sierrae; Conner et al. 2018). The scale at which we measured NDVI may not be fine enough and the relationship between NDVI and survival may not be direct enough to render NDVI as a useful metric for predicting fawn survival. In addition, a variety of greenness metrics have been derived reflecting different phases of plant phenology (Meier and Brown 2014). Possibly, a different greenness metric would provide a more appropriate match given the different phases of plant phenology represented in the 3 study areas.

Opposite to our hypothesis, we did not find a relationship between predator abundance and survival rates of pronghorn fawns; however, given only 2 years of data, the role of coyote predation cannot be completely discounted. Coyote predation was the leading cause of mortality across all 3 study areas during both years with the LLPH site having fawns with the least mass and correspondingly, the lowest fawn survival. There have been variable findings on the role of predation effects on neonate ungulates. For example, some researchers reported predators can have a major effect on neonate survival (Berger and Conner 2008, White et al. 2009). In our study, coyote predation was the highest cause of mortality and coyotes were the leading predator of fawns. Coyotes can be a significant predator on neonate pronghorn, with some studies finding coyote mortality being compensatory (Pyrah 1987, Kohlmann et al. 1999, 
Danvir 2000). Coyote removal increases fawn survival (Smith et al. 1986, Phillips and White 2003); however, coyote removal to enhance pronghorn fawn survival has not been conducted at a large scale, such as at a managementunit level, while also examining the suite of variables including climate and alternate prey. In a study in southeastern Idaho, large-scale coyote removal did not affect mule deer populations (Hurley et al. 2011). The LLPH did contain wolves (Canis lupus), which can affect predation rates of coyotes on pronghorn fawns (Berger et al. 2008) and wolves can reduce coyote density (Berger and Gese 2007).

There are certainly other factors influencing fawn survival we did not examine because we considered only factors immediately surrounding the fawning period. The presence of wolves in the LLPH study area, although not leading directly to predation of fawns, may be creating a more competitive landscape for prey, with coyotes therefore concentrating more on fawns as a summer food source. But pursuing additional factors affecting fawn survival does not appear necessary because fawn survival in some of the study areas was high. During the 2 years of our study, neonate survival across our study sites averaged $42 \%$. O'Gara and Shaw (2004) reported an average of $29 \%$ fawn survival across 18 studies; the LLPH study area had similar low fawn recruitment $(28 \%)$. In the areas with high fawn survival, we concluded that fawn survival may not be the limiting factor of population growth in those areas, and other possible factors should be examined (e.g., adult survival). Given we obtained only 2 years of data covering the first 4 months of life, assessing fawn survival over winter should be considered for future research including other factors that affect population growth rates.

One major factor we were not able to examine was winter severity. Female pronghorn coming out of a cold winter in lower nutritional condition may put more energy into restoring their body condition rather than applying that energy to their offspring (Bodie 1979), and females exiting a previous winter in poor body condition also have a higher chance of mortality during summer (Reinking et al. 2018). We recommend future research consider focusing on female survival and factors affecting female survival because it is more likely that population growth in these areas was limited by adult survival rather than fawn survival. Additionally, there is a need for future research to evaluate the relationships between forage quality and dietary characteristics, along with other habitat characteristics, and how these factors influence fawn survival and overall population performance.

\section{MANAGEMENT IMPLICATIONS}

Our findings indicate diet quality for female pronghorn during pregnancy was positively related to fawn survival. Management actions that enhance forage quality or restores habitat for higher quality forage should be considered if herd levels are below management objectives, particularly if fawn recruitment is low in that area. Federal and state land managers could plant desirable forage species (e.g., native forbs) and restore quality habitat (healthy plant communities with a diversity of shrubs, forbs, and grasses). Although high lagomorph abundance was positively related to fawn survival, lagomorph populations are cyclic and managing lagomorph density to buffer predation on pronghorn fawns seems unlikely. Maintenance of quality habitat for pronghorn will likely also benefit lagomorphs, thereby providing the additional buffering effect of alternate prey, although increased alternate prey can also increase predator populations.

\section{ACKNOWLEDGMENTS}

The findings and conclusions in this publication have not been formally disseminated by the United States Department of Agriculture and should not be construed to represent any agency determination or policy. We thank the efforts of our field technicians, including N. M. Bilodeau, C. M. de Caussin, C. E. Fust, J. P. Jaeckel, A. M. Washakowski, M. Z. Copeland, M. J. Hanneman, L. R. Perry, J. Krohner, C. Tappe, and K. M. McCarty. Our thanks to many Idaho Fish and Game personnel for their field and logistical assistance, including M. A. Hurley, S. B. Roberts, H. M. Miyasaki, C. W. Hendricks, M. P. Atwood, Z. B. Lockyer, M. C. Wackenhut, J. J. Nelson, J. Juza, J. Guthrie, E. D. Freeman, M. Horsmon, C. Hone, C. A. McClellan, J. Rydalch, D. D. Cureton, C. Rasmussen, T. Gregory, B. Stansberry, G. G. Painter, J. R. Shallow, and J. Husseman. We thank P. A. Terletzky for assistance with data management and geographic information system programming. Funding and logistical support was provided by the Idaho Department of Game and Fish, with additional support from the United States Department of Agriculture, Wildlife Services, National Wildlife Research Center.

\section{LITERATURE CITED}

Aikens, E. O., M. J. Kauffman, J. A. Merkle, S. P. Dwinnell, G. L. Fralick, and K. L. Monteith. 2017. The greenscape shapes surfing of resource waves in a large migratory herbivore. Ecology Letters 20: $741-750$.

Autenrieth, R. E., and E. Fichter. 1975. On the behavior and socialization of pronghorn fawns. Wildlife Monographs 42:3-111.

Beale, D. M. 1986. Pronghorn antelope productivity on semi-desert range in western Utah. Proceedings of the Biennial Pronghorn Antelope Workshop 12:41-42.

Beale, D. M., and A. D. Smith. 1970. Forage use, water consumption, and productivity of pronghorn antelope in western Utah. Journal of Wildlife Management 34:570-582.

Beale, D. M., and A. D. Smith. 1973. Mortality of pronghorn antelope fawns in western Utah. Journal of Wildlife Management 37:343-352.

Berger, K. M., and M. M. Conner. 2008. Recolonizing wolves and mesopredator suppression of coyotes: impacts of pronghorn population dynamics. Ecological Applications 18:599-612.

Berger, K. M., and E. M. Gese. 2007. Does interference competition with wolves limit the distribution and abundance of coyotes? Journal of Animal Ecology 76:1075-1085.

Berger, K. M., E. M. Gese, and J. Berger. 2008. Indirect effects and traditional trophic cascades: a test involving wolves, coyotes, and pronghorn. Ecology 89:818-828.

Bergerud, A. T. 1983. Prey switching in a simple ecosystem. Scientific American 249:130-141.

Bischof, R., L. E. Loe, E. L. Meisingset, B. Zimmermann, B. Van Moorter, and A. Mysterud. 2012. A migratory northern ungulate in the pursuit of spring: jumping or surfing the green wave? American Naturalist 180:407-424. 
Bishop, C. J., D. J. Freddy, G. C. White, B. E. Watkins, T. R. Stephenson, and L. L. Wolfe. 2007. Using vaginal implant transmitters to aid in capture of mule deer neonates. Journal of Wildlife Management 71:945-954.

Bishop, C. J., G. C. White, D. J. Freddy, B. E. Watkins, and T. R. Stephenson. 2009. Effect of enhanced nutrition on mule deer population rate of change. Wildlife Monographs 172:1-28.

Bishop, C. J., G. C. White, and P. M. Lukacs. 2008. Evaluating dependence among mule deer siblings in fetal and neonatal survival analyses. Journal of Wildlife Management 72:1085-1093.

Blakesley, J. A., M. E. Seamans, M. M. Conner, A. B. Franklin, G. C. White, R. J. Gutiérrez, J. E. Hines, J. D. Nichols, T. E. Munton, D. W. Shaw, et al. 2010. Population dynamics of spotted owls in the Sierra Nevada, California. Wildlife Monographs 174:1-36.

Bodie, W. L. 1979. Factors affecting pronghorn fawn mortality in central Idaho. Thesis, University of Montana, Missoula, USA.

Burnham, K. P., and D. R. Anderson. 2002. Model selection and multimodal inference: a practical information-theoretic approach. Second edition. Springer-Verlag, New York, New York, USA.

Byers, J. A. 1997. American pronghorn: social adaptations and the ghosts of predators past. University of Chicago Press, Chicago, Illinois, USA.

Caley, P. A., and C. G. Morley. 2002. Assessing growth rates of European rabbit populations using spotlight transect counts. Journal of Wildlife Management 66:131-137.

Carstensen, M., G. D. DelGiudice, and B. A. Sampson. 2003. Using doe behavior and vaginal-implant transmitters to capture neonate whitetailed deer in north-central Minnesota. Wildlife Society Bulletin 31: 634-641.

Carstensen, M., G. D. DelGiudice, B. A. Sampson, and D. W. Kuehn. 2009. Survival, birth characteristics, and cause-specific mortality of white-tailed deer neonates. Journal of Wildlife Management 73: 175-183.

Caughley, G. 1966. Mortality patterns in mammals. Ecology 47:906-918.

Clark, F. W. 1972. Influence of jackrabbit density on coyote population change. Journal of Wildlife Management 36:343-356.

Conner, M. M., T. R. Stephenson, D. W. German, K. L. Monteith, A. P. Few, and E. H. Bair. 2018. Survival analysis: informing recovery of Sierra Nevada bighorn sheep. Journal of Wildlife Management 82:1442-1458.

Danvir, R. E. 2000. Environmental and density-dependent effects on a northern Utah pronghorn population. Proceedings of the Biennial Pronghorn Antelope Workshop 17:36-41.

Dennehy, J. J. 2001. Influence of social dominance rank on diet quality of pronghorn females. Behavioral Ecology 12:177-181.

Dirschl, H. J. 1963. Food habits of the pronghorn in Saskatchewan. Journal of Wildlife Management 27:81-93.

Dunbar, M. R., and M. R. Giordano. 2003. Abundance and condition indices of coyotes on Hart Mountain National Antelope Refuge, Oregon. Western North American Naturalist 62:341-347.

Fairbanks, W. S. 1993. Birthdate, birthweight, and survival in pronghorn fawns. Journal of Mammalogy 74:129-135.

Fowler, C. W. 1987. A review of density dependence in populations of large mammals. Pages 401-441 in H. H. Genoways, editor. Current mammalogy. Springer, Boston, Massachusetts, USA.

Franklin, A. B., R. J. Gutiérrez, J. D. Nichols, M. E. Seamans, G. C. White, G. S. Zimmerman, J. E. Hines, T. E. Munton, W. S. LaHaye, J. A. Blakesley, et al. 2004. Population dynamics of the California spotted owl (Strix occidentalis occidentalis): a meta-analysis. Ornithological Monographs 54:1-54.

Gaillard, J. M., M. Festa-Bianchet, and N. G. Yoccoz. 1998. Population dynamics of large herbivores: variable recruitment with constant adult survival. Trends in Ecology and Evolution 13:58-63.

Gálvez-Cerón, A., D. Gassó, J. R. López-Olvera, G. Mentaberre, J. Bartolomé, I. Marco, D. Ferrer, L. Rossi, M. Garel, S. Lavín, et al. 2015. Gastrointestinal nematodes and dietary fibre: two factors to consider when using FN for wildlife nutrition monitoring. Ecological Indicators 52:161-169.

Gregg, M. A., M. Bray, K. M. Kilbride, and M. R. Dunbar. 2001. Birth synchrony and survival of pronghorn fawns. Journal of Wildlife Management 65:19-24.

Hamlin, K. L., S. J. Riley, D. Pyrah, A. R. Dood, and R. J. Mackie. 1984. Relationships among mule deer fawn mortality, coyotes, and alternate prey species during summer. Journal of Wildlife Management 48: 489-499.
Hansen, M. C., J. D. Yoakum, W. H. Pyle, and R. G. Anthony. 2001. New strategies for pronghorn food habit studies. Proceedings of the Biennial Pronghorn Antelope Workshop 19:71-94.

Holt, R. D. 1977. Predation, apparent competition, and the structure of prey communities. Theoretical Population Biology 12:197-229.

Hurley, M. A., J. W. Unsworth, P. Zager, M. Hebblewhite, E. O. Garton, D. M. Montgomery, J. R. Skalski, and C. L. Maycock. 2011. Demographic response of mule deer to experimental reduction of coyotes and mountain lions in southeastern Idaho. Wildlife Monographs 178:1-33.

Jensen, J. R. 2016. Introductory digital image processing: a remote sensing perspective. Fourth edition. Prentice Hall, Upper Saddle River, New Jersey, USA.

Johnson, H. E., M. Hebblewhite, T. R. Stephenson, D. W. German, B. M. Pierce, and V. C. Bleich. 2013. Evaluating apparent competition in limiting the recovery of an endangered ungulate. Oecologia 171: 295-307.

Kaplan, E. L., and P. Meier. 1958. Nonparametric estimation from incomplete observations. Journal of the American Statistical Association 53:457-481.

Keech, M. A., R. T. Bowyer, J. M. Ver Hoef, R. D. Boertje, B. W. Dale, and T. R. Stephenson. 2000. Life-history consequences of maternal condition in Alaskan moose. Journal of Wildlife Management 64:450-462.

Knowlton, F. F., E. M. Gese, and M. M. Jaeger. 1999. Coyote depredation control: an interface between biology and management. Journal of Range Management 52:398-412.

Knowlton, F. F., and L. C. Stoddart. 1992. Some observations from two coyote-prey studies. Pages 101-121 in A. Boer, editor. Ecology and management of the eastern coyote. Wildlife Research Unit. University of New Brunswick, Fredericton, Canada.

Kohlmann, S. G., D. G. Whittaker, and M. J. Hedrick. 1999. Density dependence in Great Basin pronghorn: implications for adaptive harvest management. Proceedings of the Biennial Pronghorn Antelope Workshop 18:103.

Leslie, D. M., Jr., J. A. Jenks, M. Chilelli, and G. R. Lavigne. 1989. Nitrogen and diaminopimelic acid in deer and moose feces. Journal of Wildlife Management 53:216-218.

Linhart, S. B., and F. F. Knowlton. 1975. Determining the relative abundance of coyotes by scent station lines. Wildlife Society Bulletin 3:119-124

Linnell, J., R. Aanes, and R. Andersen. 1995. Who killed Bambi? The role of predation in the neonatal mortality of temperate ungulates. Wildlife Biology 1:209-223.

Meier, G. A., and J. F. Brown. 2014. Remote sensing of land surface phenology. U.S. Geological Survey Fact Sheet 2014-3052, Sioux Falls, South Dakota, USA.

Miller, W. H., and M. Drake. 2003. Nutritional concerns of pronghorn antelope on Anderson Mesa and Garland Prairie, Arizona. Arizona Game and Fish Department, Phoenix, USA.

Monteith, K. L., V. C. Bleich, T. R. Stephenson, B. M. Pierce, M. M. Conner, J. G. Kie, and R. T. Bowyer. 2014. Life-history characteristics of mule deer: effects of nutrition in a variable environment. Wildlife Monographs 186:1-62.

Mysterud, A., B. K. Vike, E. L. Meisingset, and I. M. Rivrud. 2017. The role of landscape characteristics for forage maturation and nutritional benefits of migration in red deer. Ecology and Evolution 7: 4448-4455.

Nichols, J. D., J. E. Hines, and P. Blums. 1997. Tests for senescent decline in annual survival probabilities of common pochards, Aythya ferina. Ecology 78:1009-1018.

O'Gara, B. W. 2004. Physical characteristics. Pages 109-144 in B. W. O'Gara and J. D. Yoakum, editors. Pronghorn ecology and management. University Press of Colorado, Boulder, USA.

O'Gara, B. W., and H. G. Shaw. 2004. Predation. Pages 337-377 in B. W. O'Gara and J. D. Yoakum, editors. Pronghorn ecology and management. University Press of Colorado, Boulder, USA.

Osborn, R. G., and T. F. Ginnett. 2001. Fecal nitrogen and 2, 6diaminopimelic acid as indices to dietary nitrogen in white-tailed deer. Wildlife Society Bulletin 29:1131-1139.

Pettorelli, N. 2014. The normalized difference vegetation index. Oxford University Press, Oxford, United Kingdom. 
Phillips, G. E., and G. C. White. 2003. Pronghorn population response to coyote control: modeling and management. Wildlife Society Bulletin 31:1162-1175.

Pollock, K. H., S. R. Winterstein, and M. J. Conroy. 1989. Estimation and analysis of survival distributions for radio-tagged animals. Biometrics 45:99-109.

Pyrah, D. 1987. American pronghorn antelope in the Yellow Water Triangle, Montana: a study of social distribution, population dynamics, and habitat use. Montana Department of Fish, Wildlife, and Parks, Billings, USA.

Rachael, J., S. Nadeau, J. Powell, R. Smith, R. Berkley, T. Boudreau, C. Class, D. Meints, R. Knight, T. Keegan, et al. 2010. Pronghorn Progress Report. Idaho Department of Fish and Game, Boise, USA.

Reinking, A. K., K. T. Smith, K. L. Montheith, T. W. Mong, M. J. Read, and J. L. Beck. 2018. Intrinstic, enviromental, and anthropogenic factors related to pronghorn summer mortality. Journal of Wildlife Management 82:608-617.

Robbins, C. T. 1983. Wildlife feeding and nutrition. Academic Press, New York, New York, USA.

Robinson, M., and J. Byers. 2001. Relationships between diet quality and fecal nitrogen, fecal diaminopimelic acid and behavior in a captive group of pronghorn. Proceedings of the Biennial Pronghorn Antelope Workshop 19:28-44.

Rominger, E. M., H. A. Whitlaw, D. L. Weybright, W. C. Dunn, and W. B. Ballard. 2004. The influence of mountain lion predation on bighorn sheep translocations. Journal of Wildlife Management 68:993-999.

Sams, M. G., R. L. Lochmiller, C. W. Qualls, Jr., D. M. Leslie, Jr., and M. E. Payton. 1996. Physiological correlates of neonatal mortality in an overpopulated herd of white-tailed deer. Journal of Mammalogy 77:179-190.

Seidler, R. G., E. M. Gese, and M. M. Conner. 2014. Using sterilization to change predation rates of wild coyotes: a test case involving pronghorn fawns. Applied Animal Behaviour Science 154:83-92.

Smith, G. W., and N. C. Nydegger. 1985. A spotlight, line transect method for surveying jackrabbits. Journal of Wildlife Management 49:699-702.

Smith, R. H., D. J. Neff, and N. G. Woolsey. 1986. Pronghorn response to coyote control: a benefit: cost analysis. Wildlife Society Bulletin 14:226-231.

Smyser, T. J. 2008. Population productivity and pronghorn nutrition during lactation. Proceedings of the Biennial Pronghorn Antelope Workshop 23:127-144.
Smyser, T. J., E. O. Garton, and P. Zager. 2005. The influence of habitat variables on pronghorn recruitment. Idaho Department of Fish and Game, Boise, USA.

Stoddart, L. C., R. E. Griffiths, and F. F. Knowlton. 2001. Coyote responses to changing jackrabbit abundance affect sheep predation. Journal of Range Management 54:15-20.

Villamuelas, M., N. Fernández, E. Albanell, A. Gálvez-Cerón, J. Bartolomé, G. Mentaberre, J. R. López-Olvera, X. Fernández-Aguilar, A. Colom-Cadena, and J. M. López-Martín. 2016. The Enhanced Vegetation Index (EVI) as a proxy for diet quality and composition in a mountain ungulate. Ecological Indicators 61:658-666.

Wagner, F. H. 1981. Role of lagomorphs in ecosystems. Pages 668-694 in K. Meyers and C. D. MacInnes, editors. Proceedings of the World Lagomorph Conference. University of Guelph, Guelph, Ontario, Canada.

Wehausen, J. 1995. Fecal measures of diet quality in wild and domestic ruminants. Journal of Wildlife Management 59:816-823.

White, G. C., and K. P. Burnham. 1999. Program MARK: survival estimation from populations of marked animals. Bird Study 46:S120-S139.

White, P. J., T. L. Davis, and J. A. Byers. 2009. Predator-specific mortality of pronghorn on Yellowstone's northern range. Western North American Naturalist 69:186-194.

Whittaker, D. G., and F. G. Lindzey. 1999. Effect of coyote predation on early fawn survival in sympatric deer species. Wildlife Society Bulletin 27:256-262.

Yoakum, J. D. 1990. Food habits of the pronghorn. Proceedings of the Biennial Pronghorn Antelope Workshop 14:102-111.

Yoakum, J. D. 2004a. Distribution and abundance. Pages 75-108 in B. W. O'Gara and J. D. Yoakum, editors. Pronghorn: ecology and management. University Press of Colorado, Boulder, USA.

Yoakum, J. D. 2004b. Foraging ecology, diet studies and nutrient values. Pages 447-502 in B. W. O'Gara and J. D. Yoakum, editors. Pronghorn: ecology and management. University Press of Colorado, Boulder, USA.

Yoakum, J. D. 2006. Influences of vegetation on pronghorn in the Intermountain West. Proceedings of the Biennial Pronghorn Antelope Workshop 22:53-68.

Associate Editor: Michael Wisdom. 